\title{
PENGARUH KUALITAS INTERAKSI ATASAN- BAWAHAN DAN POLITIK ORGANISASI TERHADAP ORGANIZATIONAL CITIZENSHIP BEHAVIOR PADA PEGAWAI NEGERI SIPIL PEMERINTAH KOTA SOLOK
}

\author{
Tifanny Dyanisa \\ Zulkarnain \\ Siti Zahreni \\ email: tifannydy@gmail.com \\ Fakultas Psikologi \\ Universitas Sumatera Utara
}

\begin{abstract}
Abstrak- This study aims to determine the influence of leader-member exchange and organizational politics toward organizational citizenship behavior. The result showed that receiving Leadermember exchange positively affects to organizational citizenship behavior and organizational politics negatively affects to organizational citizenship behavior. This research indicates the importance of leader-member exchange and organizational politic toward organizational citizenship behavior.
\end{abstract}

Keyword: Leader-Member Exchange, Organizational Politic, Organizational Citizenship Behavior

PSIKOISLAMIKA. Jurnal Psikologi Islam (JPI) copyright @ 2017 Pusat Penelitan dan Layanan Psikologi. Volume 14 Nomor 2 Tahun 2017

\section{PENDAHULUAN}

Keberhasilan dan efektivitas suatu organisasi dapat tercapai ketika karyawan tidak hanya memiliki keinginan untuk dapat menyelesaikan pekerjaan sesuai tugas yang telah ditetapkan, akan tetapi mereka juga bersedia untuk melakukan pekerjaan tambahan di luar dari pekerjaan formal mereka dan mau memberikan kinerja yang melebihi harapan organisasi, perilaku seperti ini sering juga disebut dengan organizational citizenship behavior (Robbins, 2001; Organ, Podsakoff \& MacKenzie, 2006; Ramesh, 2014).

Organizational citizenship behavior diketahui sangat penting bagi efektivitas organisasi pemerintahan karena dapat membantu proses birokrat yang lamban karena minimnya sumber daya manusia ataupun karena prosedur-prosedur yang ada pada pemerintahan (Vigoda \& Golembiewski, 2001). Organizational citizenship behavior juga merupakan prasyarat terwujudnya good governance, dimana dalam mencapai good governance dibutuhkan semangat kerja yang mengarah kepada good citizenship, penerapan budaya birokrat good citizenship dapat terwujud apabila telah terbentuk organizational citizenship behavior pada diri pegawai (Karim, 2010). Di Indonesia sendiri, pelayanan publik masih banyak menerima komplain dari masyarakat, hal ini terlihat dari laporan Ombudsman (2013) yang menyatakan bahwa pemerintah daerah berada pada posisi pertama dari semua klasifikasi terlapor yang menerima keluhan mengenai buruknya pelayanan dan maladministrasi, yakni sebanyak 2329 laporan atau $45,02 \%$ dari total laporan yang masuk. Untuk itu 
perlu dilakukan penelitian mengenai organizational citizenship behavior pegawai negeri sipil dan faktor yang mempengaruhinya. Di dalam penelitian ini, kami berasumsi bahwa kualitas interaksi atasanbawahan dan politik organisasi dapat mempengaruhi organizational citizenship behavior pegawai negeri sipil. Melalui penelitian ini, kami berharap untuk memberikan bukti ilmiah tentang pentingnya kualitas interaksi atasan-bawahan dan politik organisasi dalam terwujudnya organizational citizenship behavior pegawai negeri sipil.

\section{Organizational Citizenship Behavior}

Istilah organizational citizenship behavior pertama kali dikemukan oleh Dennis Organ pada awal tahun 1980-an dan telah menjadi landasan teori sikap kerja. Organ (1997) mendefinisikan organizational citizenship behavior sebagai perilaku yang ditampilkan oleh seorang karyawan atas dasar kemauannya sendiri, terlepas dari ketentuan atau kewajiban yang dibebankan kepadanya dengan tujuan untuk mencapai tujuan dan efektivitas organisasi, sehingga tidak mempengaruhi sistem reward maupun punishment pada seorang karyawan. Contoh perilaku ini meliputi bantuan kepada teman kerja untuk meringankan beban kerja mereka, tidak banyak waktu beristirahat, melaksanakan tugas yang tidak diminta atasan dan membantu orang lain untuk menyelesaikan masalah.

Menurut Jex \& Britt (2008) secara umum organizational citizenship behavior mengacu kepada perilaku yang bukan bagian dari deskripsi pekerjaan formal karyawan (misalnya, membantu rekan kerja yang telah absen; sopan kepada orang lain) atau perilaku yang karyawan tidak secara resmi dihargai. Greenberg (2010) menyatakan bahwa organizational citizenship behavior merupakan perilaku yang dilakukan oleh karyawan untuk meningkatkan hubungan sosial dan kerjasama dengan organisasi namun perilaku tersebut berada diluar dari tugastugas formalnya.

Organizational citizenship behavior merupakan perilaku karyawan yang memberikan kontribusi melebihi dari deskripsi jabatannya secara suka rela dan tidak berhubungan dengan sistem reward pada sebuah organisasi untuk mencapai tujuan, efektivitas dan efisiensi organisasi.

\section{Kualitas Interaksi Atasan-Bawahan}

Teori kualitas interaksi atasan-bawahan pertama kali diperkenalkan oleh Dansereau, Graen, \& Cashman pada tahun 1970-an (Liden, Sparrowe
\& Wayne, 1997). Dasereau, Graen \& Haga (1975) mengatakan pada teori kualitas interaksi atasanbawahannya bahwa pemimpin menampilkan perilaku yang berbeda bawahannya dan pola perilaku tersebut berkembang dari waktu ke waktu. Jika bawahan merasakan adanya kualitas yang tinggi pada hubungan mereka dengan atasan mereka itu artinya bawahan masuk kepada in-group, sedangkan bawahan yang merasakan kualitas hubungan dengan atasannya rendah maka bawahan masuk kepada out-group (Landy \& Conte, 2004). Graen \& Uhl-bien (1995) menyatakan kualitas interaksi atasan-bawahan sebagai pendekatan pertukaran sosial kepemimpinan.

Liden \& Maslyn (1998) memberikan pandangan baru terhadap teori kualitas interaksi atasan-bawahan, dimana ia mendefinisikan kualitas interaksi atasanbawahan sebagai dinamika hubungan antara atasan dan bawahan yang bersifat multidimensional dalam suatu dyad yang terdiri atas empat dimensi yaitu kontribusi, loyalitas, afeksi, dan respek terhadap profesi. Sejalan dengan ini, Schriesheim \& Cogliser (1999) juga menyatakan bahwa konsep utama dari kualitas interaksi atasan-bawahan memfokuskan kepada hubungan atasan dengan bawahan.

Yukl (2002) menjelaskan bagaimana atasan dan bawahan mengembangkan hubungan saling mempengaruhi satu sama lain dan menegosiasikan peran bawahan dalam satu organisasi. Kualitas interaksi atasan-bawahan tidak hanya melihat perilaku atasannya saja tetapi menekankan kepada kualitas hubungan antara atasan dan bawahan. Jex \& Britt (2008) mengatakan kualitas interaksi atasan-bawahan sebagai hubungan yang unik antara pemimpin dan bawahan, yang mencerminkan pertukaran sosial antara pemimpin dengan bawahannya.

Kualitas interaksi atasan-bawahan adalah penilaian karyawan terhadap hubungannya dengan atasannya yang merupakan dalam suatu dyad (kelompok yang terdiri dari dua orang) yang saling mempengaruhi satu sama lainnya.

\section{Politik Organisasi}

Ferris \& Kacmar (1992) mendefinisikan politik organisasi sebagai perilaku mementingkan diri sendiri oleh karyawan untuk mencapai kepentingan pribadi, keuntungan dan manfaat dengan mengorbankan orang lain dan terkadang bertentangan dengan kepentingan seluruh organisasi atau unit kerja. Cropanzo \& Kacmar (1995) mendefinisikan politik organisasi sebagai perilaku mempengaruhi orangorang yang dapat memberikan manfaat dalam 
rangka melindungi kepentingan diri sendiri.

Vigoda (2000) menyatakan bahwa politik organisasi merupakan perilaku yang sering dikaitkan dengan manipulasi, pencemaran nama baik, subversiveness dan cara-cara tidak sah menggunakan kekuasaan untuk mencapai tujuan seseorang. Greenberg \& Baron (2000) mendefinisikan politik organisasi sebagai penggunaan kekuasaan secara tidak resmi untuk melindungi kepentingan pribadi.

Andrews \& Kacmar (2001) juga mendefinisikan politik organisasi sebagai perilaku yang dilakukan oleh individu untuk kepentingan diri mereka sendiri tanpa memperhatikan kesejahteraan orang lain ataupun organisasi tempat mereka bekerja. Verdacsa (2011) menyatakan bahwa politik organisasi melibatkan tindakan yang disengaja untuk melindungi kepentingan pribadi dan kelompok, yang bertujuan untuk meningkatkan posisi pribadi melalui intimidasi atau pelecehan.

Politik organisasi adalah tindakan yang dilakukan karyawan untuk mencapai tujuan pribadinya tanpa menghiraukan kepentingan karyawan lain maupun organisasinya.

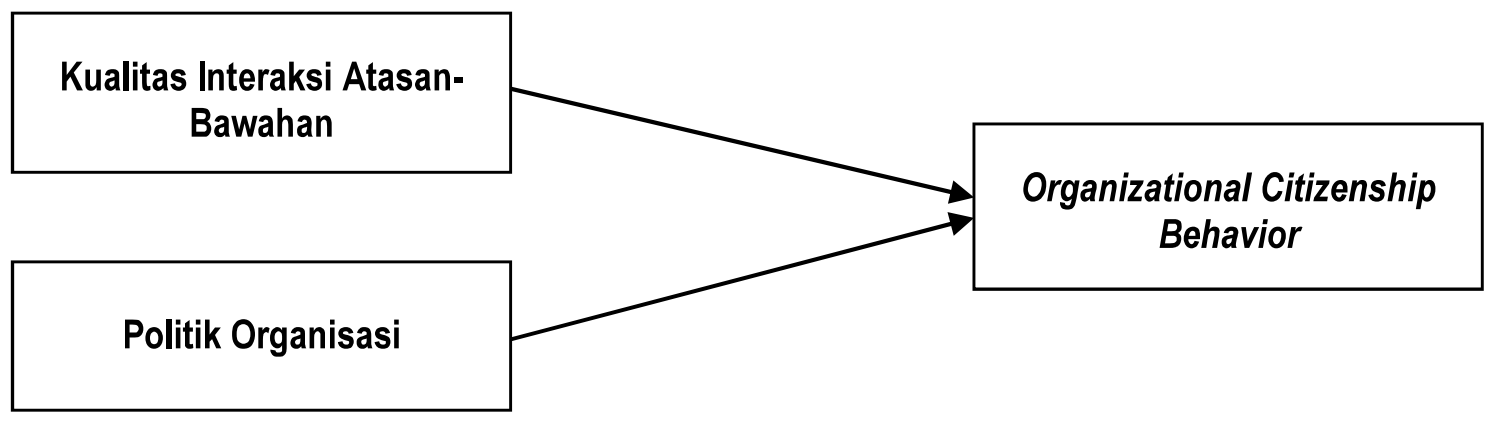

Gambar 1:

Kerangka Pikir Penelitian

\section{METODE}

Penelitian ini termasuk kategori penelitian korelasional dengan dua variabel bebas, yaitu kualitas interaksi atasan-bawahan (X1) dan politik organisasi $(\mathrm{X} 2)$, dan satu variabel terikat, yaitu organizational citizenship behavior $(\mathrm{Y})$. Adapun subjek penelitian berjumlah 286 Pegawai Negeri Sipil dengan status Fungsional Umum di Lingkungan Pemerintah Kota Solok.

Untuk keperluan penelitian ini, kami membuat angket yang berisi skala-skala untuk mengukur variable-variabel penelitian. Kami menyebarkan angket ini kepada para partisipan untuk diisi. Angket kami kumpulkan setelah para partisipan menyelesaikan pengisian. Semua aitem kami buat dalam bentuk skala Likert lima titik (1= sangat tidak sesuai, $5=$ sangat tidak sesuai; sebagian aitem kami konstruksi secara terbalik). Kualitas interaksi atasan-bawahan kami ukur dengan skala yang kami konstruksikan berdasarkan Liden \& Maslyn (1998). Skala kualitas interaksi atasan-bawahan ini sudah mencakup keempat aspek, yaitu aspek kontribusi (6 aitem), afeksi (6 aitem), loyalitas (5 aitem) dan professional respect (5 aitem), total aitem 22 aitem dengan koefisien korelasi aitem total berkisar dari 0.493 sampai dengan 0.824 , a $=0.951$ (e.g., "Atasan memberikan tugas tanpa menjelaskan rincinannya", "Saya senang bekerja dengan atasan saya").

Politik organisasi kami ukur dengan skala yang kami konstruksikan berdasarkan Ferris \& Kacmar (1992), skala politik organisasi ini sudah mencakup ketiga aspek, yaitu general political behavior ( 5 aitem), going along to get ahead ( 3 aitem) dan pay and promotion ( 6 aitem), total aitem 14 aitem, dengan koefisien korelasi aitem total berkisar dari 0.327 sampai dengan 0.686 , a $=0.870$ (e.g., "Pegawai yang ada pada kantor ini saling sikut dibelakang","Promosi pada organisai ini hanya untuk karyawan yang memiliki kinerja yang baik").

Organizational citizenship behavior menurut Organ (1988). Skala Organizational citizenship behavior ini sudah mencakup kelima aspek, yaitu altruism (5 aitem), conscientiousness (4 aitem), sportsmanship (5 aitem), courtesy (4 aitem) dan civic virtue ( 5 aitem), total aitem 23 aitem dengan koefisien korelasi aitem total berkisar dari 0.304 sampai dengan 0.593, $a=0.877$ (e.g., "Saya bersedia untuk meluangkan waktu saya demi membantu rekan 
kerja saya yang belum menyelesaikan pekerjaan kantornya", "Saya enggan berangkat kekantor ketika cuaca tidak mendukung").

Untuk keperluan skoring, kami menggunakan titik-tengah (mid-point) skala sebagai tolak-ukur (netral) kualitas interaksi atasan-bawahan, politik organisasi dan organizational citizenship behavior. Dengan cara ini kualitas interaksi atasan-bawahan dikategorikan baik apabila skor skala yang ditunjukkan tinggi, dan dikategorikan buruk kapabila skor yang ditunjukkan rendah. Untuk skala politik organisasi akan dikategorikan tidak kondusif apabila skor yang ditunjukkan tinggi dan dikategorikan kondusif ketika skor yang ditunjukkan rendah. Untuk skala organizational citizenship behavior akan dikategorikan cenderung tinggi apabila skor yang ditunjukkan tinggi dan akan dikategorikan cenderung rendah apabila skor yang ditunjukkan rendah.

Metode analisa data menggunakan analisa statistik multiple regression dibantu dengan program SPSS 17.00 for windows.

\section{HASIL}

Hasil penelitian menunjukkan bahwa kualitas interaksi atasan-bawahan dan politik organisasi berpengaruh terhadap organizational citizenship behavior $\left(\mathrm{R}=.758, \mathrm{R}^{2}=.334, \mathrm{~F}=70.910 ; \mathrm{P}<0.05\right)$. Kualitas interaksi atasan-bawahan berpengaruh positif dan politik organisasi berpengaruh negatif terhadap organizational citizenship behavior. Kualitas interaksi atasan-bawahan memiliki sumbangan lebih besar terhadap organizational citizenship behavior $(\mathrm{R}$ square change $=.257$ ) dibandingkan dengan politik organisasi ( $R$ square change $=.106)$, hal ini menunjukkan bahwa kualitas interaksi atasan-bawahan memiliki pengaruh yang lebih besar terhadap organizational citizenship behavior karyawan dibandingkan politik organisasi.

\section{DISKUSI}

Di dalam penelitian ini, kami memeriksa pengaruh kualitas interaksi atasan-bawahan dan politik organisasi terhadap organizational citizenship behavior Pegawai Negeri Sipil Pemerintah Kota Solok. Hasil penelitian ini menunjukkan hubungan positif antara kualitas interaksi atasan-bawahan dengan organizational citizenship behavior, artinya semakin baik kualitas interaksi atasan-bawahan dinilai karyawan, maka akan semakin tinggi pula kecenderungan organizational citizenship behavior karyawan. Hubungan negatif ditunjukkan pada politik organisasi dan organizational citizenship behavior dimana semakin tidak kondusif politik organisasi yang dirasakan karyawan, maka akan semakin rendah kecenderungan organizational citizenship behavior karyawan.

Secara khusus, penelitian ini mendukung hasilhasil penelitian sebelumnya tentang pengaruh kualitas interaksi atasan-bawahan dan politik organisasi terhadap organizational citizenship behavior (e.g., Cropanzano, Howes, Grandey \& Toth, 1997; Valle \& Perrewe, 2000; Vigoda, 2000; Murphy, Wayne, Liden \& Erdogan, 2003; Mensah, 2013). Namun demikian, penelitian ini dapat dikatakan cukup unik karena objek eksplorasi berfokus kepada Pegawai Negeri Sipil dengan status Fungsional Umum.

Selanjutnya, kami menyadari berbagai kekurangan dari penelitian ini. Pertama, dalam penelitian ini, kami hanya mengasumsikan dengan berdasarkan penemuan-penemuan di Negara lain, sementara pengaruh kualitas interaksi atasan-bawahan dan politik organisasi terhadap organizational citizenship behavior di Indonesia tidak kami sajikan. Dengan demikian, akan sangat baik jika penelitian selanjutnya mempertimbangkan faktor lain yang dapat mempengaruhi organizational citizenship behavior seperti faktor budaya ketimuran yang ada di Indonesia, yakni budaya gotong royong, dimana masyarakat Indonesia sudah terbiasa untuk saling membantu dan bertoleransi dengan orang lain, sehingga hal ini dapat mempengaruhi kecenderungan subjek untuk menunjukkan organizational citizenship behavior, kedua kami tidak melibatkan faktor lain seperti umur, masa kerja dan tingkat pendidikan subjek dalam menganalisa data, sehingga tidak diketahui variasi yang mungkin terjadi akibat kontribusi faktor tersebut. Ketiga yang sebaiknya menjadi perhatian adalah budaya patrimonial yang berkembang pada dunia birokrat, dimana budaya organisasi penyelenggara pelayanan publik di Indonesia masih banyak terikat oleh tradisi-tradisi politik dan budaya masyarakat setempat yang seringkali tidak kondusif (Effendi, 1995) sehingga berada dalam situasi politik yang tidak kondusif menjadi hal yang biasa dan lumrah bagi Pegawai Negeri Sipil di Indonesia dan tidak mempengaruhi kinerja mereka.

\section{KESIMPULAN}

Kualitas interaksi atasan-bawahan terbukti memiliki pengaruh yang positif terhadap organizational citizenship behavior pada Pegawai Negeri Sipil di Pemerintah Kota Solok. Hal ini menunjukkan bahwa semakin baik kualitas interaksi atasan-bawahan 
maka akan semakin semakin tinggi organizational citizenship behavior PNS Pemerintah Kota Solok. Politik organisasi terbukti memiliki pengaruh yang negatif terhadap organizational citizenship behavior pada Pegawai Negeri Sipil di Pemerintah Kota Solok. Hal ini menunjukkan bahwa semakin tidak kondusif politik organisasi yang dirasakan PNS maka akan semakin rendah kecenderungan

\section{DAFTAR PUSTAKA}

Cropanzano, R.S., Howes, J.C., Grandey, A.A., \& Toth, P., (1997). The relationship of organizational politics and support to work behaviors, attitudes, and stress. Journal of Organizational Behavior, 18, 159-180

Effendi, S. (1995). Kebijaksanaan Pembinaan Organisasi Publik Pada PJP II, Percikan Pemikiran Awal. Makalah Pelatihan Analisis Kebijakan Sosial Angkatan III, Yogyakarta.

Ferris, G. R., \& Kacmar, K. M. (1992). Perception of organizational politics. Journal of Management, 18 (1), 93-116

Karim, A. (2010). Pengaruh disiplin, etos kerja, dan budaya organisasi terhadap organizational citizenship behavior pegawai administrator pelabuhan tanjung priok. Pusat Pelatihan Perhubungan Laut. 13(1), 21-30.

Liden, R. C., \& Maslyn, J. M. (1998). Multidimensionality of leader-member exchange: An empirical assessment through scale development. Journal of Management, 24(l): 43-73

Mensah, G.T. (2013). The relationship between perceived organizational politics, organizational commitment and organizational citizenship behavior among some selected public sector organizations in Accra. (Thesis). University of Ghana.

Murphy, S. M., Wayne, S. J., Liden, R. C. \& Erdogan, B. (2003). Understanding social loafing: The organizational citizenship behavior PNS Pemerintah Kota Solok. Kualitas interaksi atasan-bawahan dan politik organisasi memberikan pengaruh signifikan secara bersama-sama terhadap organizational citizenship behavior pada Pegawai Negeri Sipil di Pemerintah Kota Solok. Artinya kualitas interaksi atasan-bawahan dan politik organisasi berperan terhadap organizational citizenship behavior.

role of justice perceptions and exchange relationships. Human Relations, 56 (1), 61-84.

Organ, D.W., Podsakoff,P.M, \& MacKenzie,S.B. (2006). Organizational citizenship behaviour: Its nature, antecedents, and consequences. Amerika: SAGE Publication

Ramesh, V. (2014). Organizational citizenship behaviours: A critical review of the theoretical and empirical literature and suggestions for future research. International Journal of Business and Administration Research Review, 3(6), 176-182

Robbins, S.P. (2001). Organizational behavior, (9 $\left.{ }^{\text {th }}\right)$. New Jersey: Prentice Hall

Valle, M \& Perrewe, P. (2000). Do politics perceptions relate to political behaviors? Tests of an implicit assumption and expanded model. Human Relations, 53(3), 359-386

Vigoda, E. (2000). Organizational politics, job attitudes and work outcomes: explaration and implications for the public sector. Journal of Vocational Behavior. 57, 326-347.

Vigoda, E \& Golembiewski, R.T.(2001). Governance citizenship behavior and the spirit of new managerialism: A theoretical framework an challenge for governance. American Review of Public Administration, 31(2), 273-295. 